\title{
DE MAATSCHAPPELIJKE ROL VAN DE ACCOUNTANT
}

\section{door J. H. Blokdijk}

In het begin van de zeventiger jaren ontstond in het maatschappelijk verkeer stijgende interesse in de rol van de accountant. Die belangstelling was niet altijd even welwillend en dat bracht het Bestuur van het NIvRA in 1971 tot de instelling van een Commissie Toekomstverkenning die in een halfjaar tijd het rapport „De accountant, morgen?" (9) produceerde. Dit rapport bereikte zijn hoofddoel: het losmaken van een discussie in accountantskringen over de maatschappelijke rol van de accountant.

Een zeker maatschappelijk bewustzijn was de Nederlandse accountant op dat moment stellig niet vreemd; integendeel, sedert de rede van Limperg voor het Tweede Internationale Accountantscongres van 1926 (15) en vooral sinds zijn ar. tikelenserie van 1932/33 (16) zijn alle Nederlandse accountants vertrouwd met de gedachte dat de bestaansgrond voor accountantsverklaringen gelegen is in de functie die deze verklaringen in het maatschappelijk verkeer vervullen. Deze gedachte is Limpergs belangrijkste bijdrage aan de ontwikkeling van het accountantsberoep geweest en hij was daarmee - internationaal gezien - zijn tijd vooruit.

In de daarop volgende decennia werd echter weinig aan Limpergs theorie toe. gevoegd; de gedachten dreigden te verstarren tot staande uitdrukkingen zoals "vertrouwensman van het maatschappelijk verkeer” en „leer van het gewekte vertrouwen". Toen buitenstaanders, zonder voldoende kennis van de achterliggende ideeën, zich van deze uitdrukkingen meester maakten en er een eigen in. terpretatie aan gaven, moest het beroep in actie komen.

De beroepsorganisatie heeft de discussie op velerlei wijzen gestimuleerd en de gevolgen hiervan werken nog dagelijks door in de activiteiten van dit Instituut: het aantal maatschappelijke contacten van het NIvRA is in vergelijking met zo'n tien jaar geleden verveelvoudigd. De theoretische discussie is echter wat uitgedoofd. De oorzaak hiervan lijkt mij gelegen in het bij vele studies gekozen uitgangspunt: de behoeften van degenen die van een verantwoording kennis kun. nen nemen. In een aantal publikaties, met name over "sociale verslaggeving”, worden allerlei groepen belanghebbenden opgesomd; vervolgens wordt, veelal kritiekloos, aangegeven welke behoeften deze groepen hebben, geacht worden te hebben, dan wel zouden behoren te hebben. Deze benadering, die aan buik. sprekerij doet denken, lijkt weinig vruchtbaar, mede omdat partijen zelf thans nog weinig meer dan incidentele interesse aan de dag leggen. Deze studies hebben wel de verdienste gehad dat het accountantsberoep de maatschappij niet meer als een ongedifferentieerd geheel ziet. Voor de huidige en de toekomstige plaats. bepaling van het beroep is dit van wezenlijke betekenis.

In 1973 kiest Bindenga in zijn dissertatie (2) een andere invalshoek: hij onderzoekt de ,institutionalisering” van het accountantsberoep. Deze benadering is op zichzelf zeer belangwekkend, maar behoeft uitdieping: de fenomenologische beschrijving van een "institutie” kan moeilijk richtinggevend zijn voor de verdere ontwikkeling hiervan. In een vrije maatschappij komt een instituut immers niet 
uit de lucht vallen: in het maatschappelijk leven ontstaat „,iets”, dat later geïnstitutionaliseerd wordt. Het levende ,iets" waaruit uiteindelijk de accountantsfunc. tie voortkomt, is mijns inziens een bepaalde vorm van relatie tussen personen en/of instellingen en wel de relatievorm waarbij het afleggen van verantwoor. ding past.

Die relatievorm zal dan ook het uitgangspunt van de analyse moeten zijn; deze zal zich vooral moeten richten op het wezen, het karakter van een verantwoor. ding. In dit artikel zal hiertoe een poging worden gedaan.

\section{Vrijheid en verantwoordelijkheid}

In de vroegste stadia van de menselijke beschaving was de behoeftenbevrediging een familie-aangelegenheid; arbeidsverdeling bestond slechts binnen de familie. Een belangrijke stap in de menselijke ontwikkeling werd gezet toen de arbeids. verdeling werd uitgebreid tot buiten die kring: men ontdekte dat hiermee een hoger niveau van behoeftenbevrediging werd bereikt. Hoe beter men erin slaag. de de behoeften van anderen te bevredigen, des te beter kon men ook in de eigen behoeften voorzien. Dit alles geschiedde op basis van autonome initiatieven; het was - in beginsel - een ontplooiing in vrijheid.

Die vrijheid kwam in de praktijk lang niet iedereen ten goede. Een van de be langrijkste oorzaken hiervan was het ontstaan van samenwerkingsverbanden, op grond van de gedachte of de ervaring dat vele behoeften gemakkelijker, of zelfs uitsluitend, door samenwerking bevredigd konden worden. Hoe groter en hech ter een samenwerkingsverband werd, des te groter werden de mogelijkheden om inbreuk te maken op de vrijheid van anderen. Het is nog slechts iets meer dan een eeuw geleden dat in de meeste landen een eind gemaakt werd aan de vol ledige vrijheidsberoving, de slavernij!

Arbeidsverdeling buiten familieverband veronderstelt het bestaan van een ge meenschap, een maatschappij en daarin bestaat al gauw behoefte aan een orde nende kracht, een overheid. Om ongewenste inbreuken op de vrijheid van de le den van de maatschappij te voorkomen kan de overheid in beginsel twee methoden hanteren: het aan voorwaarden binden c.q. volledig verbieden van bepaalde gedragingen, of het voorschrijven van de gehele bij de behoeftenbevrediging te volgen gedragslijn. De eerste methode beperkt de vrijheid, de tweede doet deze teniet.

Voor de bevrediging van vele behoeften is de eerste methode stellig de doel matigste: het ligt nu eenmaal in de menselijke aard dat men zich meer inspant voor de bevrediging van de behoeften van een ander indien men daar zelf belang bij heeft. Dit is de drijvende kracht achter de vrije ondernemingsgewijze produk tie. Men zal dan steeds nieuwe wegen zoeken om tot betere resultaten te komen; de andere kant van de medaille is dat daarbij steeds andere, nieuwe gedragingen tot ontwikkeling komen, waarvan niet bij voorbaat vaststaat dat zij geen onge wenste inbreuk op de vrijheid van anderen maken. De overheid moet hier orde nend optreden door het geven van verboden en conditionele geboden (d.w.z. ge boden die gelden indien men zich - vrijwillig - in een bepaalde situatie plaatst).

De complexiteit, die het gevolg is van de zojuist gesignaleerde menselijke vindingrijkheid, maakt het de overheid echter onmogelijk alleen uit eigen waarne ming alle ontwikkelingen tijdig te onderkennen.

$m a b$ blz 483 
Van der Hooft wijst er in zijn bekroonde essay (12) op dat de laatste decennia personen en samenwerkingsverbanden met gelijk gerichte belangen zich dan ook in toenemende mate bundelen tot maatschappelijke groeperingen, in instellin. gen die de ontwikkelingen waarnemen en toetsen aan de belangen van hun leden. Deze instellingen trachten op allerlei wijzen de ordening door de overheid te beïnvloeden. Zij richten hun belangstelling echter ook rechtstreeks op die sa. menwerkingsverbanden waarmee hun leden een relatie (zouden kunnen) hebben. Van der Hooft stelt zelfs dat deze instellingen in het maatschappelijk verkeer in belangrijke mate de plaats van de eigenlijke belanghebbenden hebben inge. nomen; het lijkt mij dat dit een hoofdoorzaak is van de verlevendiging van het maatschappelijk verkeer in de laatste jaren.

Personen, samenwerkingsverbanden en instellingen zijn in beginsel onderling onafhankelijk. Om hun doel te bereiken en hun functie te vervullen moeten zij echter vaak verbintenissen met anderen aangaan, waaruit een zekere wederzijdse afhankelijkheid ontstaat. Maar ook zonder verbintenissen kunnen relaties ont. staan, en wel uit hoofde van gemeenschappelijke of strijdige belangen.

De deelnemers aan het maatschappelijk verkeer hebben regelmatig de behoef. te hun vrije relatie te evalueren, vast te stellen of deze moet worden voortgezet of beëindigd, of een houding van samenwerking, van wedijver of van strijd moet worden aangenomen. Voor een dergelijke evaluatie van het tot dusverre gevoer. de eigen beleid in deze moet men beschikken over de uitkomsten van dat beleid. Daartoe is niet alleen informatie nodig over hetgeen men zelf bereikt heeft, maar ook over de situatie van anderen, van degenen met wie men een relatie onder. houdt of overweegt, en over de te verwachten ontwikkelingen daarin.

Laatstbedoelde informatie moet opgeleverd worden door die anderen: perso. nen, samenwerkingsverbanden of instellingen. Het spreekt echter zeker niet van. zelf dat men die informatie ook ter beschikking zal stellen: dit impliceert toch een zekere aantasting van de vrijheid.

Als men in een relatie een zekere overwicht op de ander heeft, kan men die informatie evenwel afdwingen. Dat gebeurt ook vaak, maar de basis hiervoor is dan een soort recht van de sterkste, waarin een overheid die zijn ordenende taak goed opvat, op den duur niet kan berusten. Er moet dan een institutionalisering plaatsvinden op een andere grondslag dan macht. Deze is slechts te vinden in een maatschappelijke verantwoordelijkheid die verder gaat dan het blijven binnen de grenzen van de door de overheid gegeven verboden en conditionele geboden. Die maatschappelijke verantwoordelijkheid vindt zijn oorsprong in de erkenning dat men met het optreden in (beperkte) vrijheid de belangen van anderen kan raken; voor het gebruik van die vrijheid moet men zich dan - als uitvloeisel van die erkenning - tegenover die belanghebbenden verantwoorden. Op basis van die verantwoording kunnen belanghebbenden beslissen over voortzetting, wijziging of verbreking van de relatie.

De informatie aan belanghebbenden wordt hun dus verstrekt als verantwoor. ding. Maar dit heeft consequenties voor de aard van de informatie: de inhoud moet qua karakter in overeenstemming zijn met de vrijheid èn met de verant. woordelijkheid. Zoals nog nader aannemelijk zal worden gemaakt kan een wij. ziging in de aard van de te verstrekken informatie gemakkelijk een tevoren niet goed overzienbare wijziging in de maatschappelijke verhoudingen teweeg bren. gen. Het is daarom noodzakelijk dieper in te gaan op de vraag: wat is een ver- 
antwoording? Tot goed begrip van het vervolg zij hier aangetekend dat verantwoordelijkheid slechts bij natuurlijke personen kan berusten; een rechtspersoon kan slechts aansprakelijk gesteld worden. Waar over de verantwoordingsplichtige wordt gesproken, wordt bij samenwerkingsverbanden dus gedoeld op de bestuur. ders. Ook de term belanghebbenden eist enige verklaring: deze omvat in beginsel elke denkbare betrokkene, behalve de verantwoordingsplichtige.

Alvorens het betoog voort te zetten moet ik erkennen dat het geschetste beeld van de maatschappelijke verantwoordelijkheid in het stelsel van vrije onderne. mingsgewijze produktie vooralsnog een nogal idealistische schildering is. Dit moet worden toegeschreven aan het feit dat de verantwoording, waarin de maatschappelijke verantwoordelijkheid gestalte krijgt, nog slechts ten dele geïnstitutionaliseerd is.

Tot dusverre is slechts de verantwoording aan de verschaffers van risicodra. gend vermogen wettelijk geregeld, zij het dat deze - o.a. via de pubikatieplicht vaak ook aan andere belanghebbenden ter beschikking wordt gesteld. De bevoor. rechte positie van de verschaffers van risicodragend vermogen is historisch goed verklaarbaar: hun functie is een afsplitsing van die van de „eigenaar” die bezat èn beheerde en de splitsing van eigendom en beheer was zonder verantwoor. dingsplicht niet te realiseren. Deze splitsing brengt met zich mee dat de verschaffers van risicodragend vermogen in beginsel de verantwoordingsplichtige door een andere natuurlijke persoon kunnen vervangen. De andere belanghebbenden (leveranciers, werknemers, financiers enz.) zijn niet van binnenuit maar van bui. tenaf gekomen, hetgeen met zich mee heeft gebracht dat zij de verantwoordingsplichtige alleen kunnen beïnvloeden door wijzigingen in hun relatie.

De verantwoording aan deze groepen belanghebbenden wordt door dezen vaak nog als onvolledig ervaren. Hoewel institutionalisering van een maatschap. pelijke verantwoording nog niet op handen lijkt, worden er - onder etiketten als „sociale verslaggeving” en „omgevingsverslag” - duidelijke pogingen gedaan de grondgedachte van een dergelijke verantwoording ingang te doen vinden. Te verwachten is dat dit in belangrijke mate gestimuleerd, zo niet afgedwongen, zal worden door het optreden van de instellingen die de belangen van gehele maatschappelijke groeperingen beogen te behartigen. In dit licht is een analyse van het begrip ,verantwoording” thans stellig niet overbodig.

Bij deze analyse zal impliciet worden uitgegaan van de vrije ondernemingsgewijze produktie, de autonome ontplooiing van de behoeftenbevrediging. De be. ginselen waarop deze analyse gebaseerd is gelden ook waar de overheid de be. hoeftenbevrediging volledig regelt door middel van (absolute) geboden, zolang er maar enige vrijheid bestaat. Deze situatie is echter vooralsnog niet expliciet in be. schouwing genomen.

\section{De aard van een verantwoording}

De verantwoording concretiseert de verantwoordelijkheid voor het gebruik van de vrijheid.

De inhoud van een verantwoording moet in overeenstemming zijn met de vrij heid èn met de verantwoordelijkheid van de verantwoordingsplichtige. Een ver. antwoording moet de verantwoordelijkheid tot uitdrukking brengen zonder de vrijheid in wezen aan te tasten. 
In het navolgende wordt getracht deze vage, tegenstrijdig klinkende beginselen af te wegen en te concretiseren, en daardoor de grenzen van de inhoud van een verantwoording aan te geven. Die grenzen kunnen naar mijn mening op de hier na volgende wijze gekenschetst worden.

\section{Uitkomsten, geen methoden}

Men is verantwoordelijk voor zijn daden. In een vrije maatschappij betekent dit dat men de gevolgen van zijn daden moet dragen; daarom moet men in een ver. antwoording de uitkomsten van zijn activiteiten weergeven. De uitkomsten omvat. ten uiteraard méér dan het eindcijfer van de resultatenrekening; de verantwoor. ding moet de relevante aspecten weergeven van de situatie waarin men door zijn daden is beland. De daden zelf worden slechts be- en eventueel veroordeeld indien de verdenking bestaat dat verboden overtreden en/of conditionele geboden niet nageleefd zijn. In een vrije maatschappij bestaat evenwel geen verplichting tot zelfbeschuldiging, zodat er ook langs deze weg geen verplichting kan en mag worden geconstrueerd tot vermelding van de methoden waarmee de uitkomsten zijn bereikt. Aan een verantwoording kan dan ook niet de eis gesteld worden dat deze een morele of ideologische beoordeling van het handelen toelaat; de verplichting zich aan een dergelijke beoordeling te onderwerpen werkt in beginsel vrijheids. berovend. Als de overheid het handelen binnen door haar gestelde grenzen vrij laat, behoort men de verantwoordingsplichtige niet te dwingen die vrijheid aan anderen prijs te geven. Dit neemt uiteraard niet weg dat belanghebbenden het recht moeten hebben het handelen te beïnvloeden, maar dat moeten zij dan doen door voorwaarden te verbinden aan hun medewerking.

Het komt voor dat een verantwoordingsplichtige informatie geeft over de me. thoden die hij heeft toegepast en de overwegingen die hem daartoe gebracht hebben.

Dit geschiedt veelal in situaties waarin hij vermoedt dat belanghebbenden hun relatie met hem in ongunstige zin dreigen te wijzigen, en die informatie heeft dan de teneur ongunstige uitkomsten toe te schrijven aan niet of nauwelijks beïn. vloedbare factoren. Deze informatieverstrekking beoogt in feite een oneigenlijke overdracht van verantwoordelijkheid aan belanghebbenden, die deze achteraf uiteraard moeilijk kunnen overnemen. Dergelijke uitingen behoren qua karakter dan ook niet tot de eigenlijke verantwoording te worden gerekend.

\section{Feiten, geen meningen}

Deze begrenzing lijkt misschien wat overbodig: men verantwoordt zich niet met (eigen) meningen, maar met feiten! Bovendien behoort in een vrije maatschappij niemand verplicht te worden zijn meningen te geven: daarmee zou in feite de ver. plichting ontstaan zich aan een morele of ideologische beoordeling te onderwer. pen en wel in veel sterkere mate dan door mededeling van de methoden waar. mee de uitkomsten bereikt zijn.

Het achterwege laten van meningen in een verantwoording houdt ook de re latie tot degenen die kennis moeten nemen van de verantwoording zuiver. Zij zijn het die een mening moeten vormen voordat zij over de toekomstige ontwikkeling van hun relatie met de verantwoordingsplichtige beslissen. 
Het is overigens niet zeker of het vorenstaande tot de communis opinio gerekend mag worden. De Werkgroep Management Audit van het NIvRA oppert in een in 1977 verschenen studierapport (18) de mogelijkheid dat men - naast de financiële en sociale informatieverstrekking - verantwoording gaat afleggen over de ,conditie” van de organisatie van het samenwerkingsverband. Uit het rapport wordt niet duidelijk wat die „verantwoording” dan zou moeten omvatten. Aangezien het om de conditie van de organisatie gaat, dringt zich de indruk op dat de verantwoordingsplichtige een mening geeft, in de zin van „de conditie is goed maar kan op enkele punten verbeterd worden”. Dit is geen verantwoording, maar een min of meer openhartige advertentie.

Anderzijds brengt de werkgroep ook de mogelijkheid van certificering van deze „verantwoordingen" door externe deskundigen ter sprake. Dat leidt weer tot de veronderstelling dat aan een mededeling van feiten gedacht is, want certificering van meningen is zinloos. Een beschrijving van de organisatie lijkt op het eerste gezicht goed als verantwoording te kunnen dienen. De organisatie is echter een methode, en zoals onder 1 . is gesteld, behoren methoden niet in een verantwoording te worden opgenomen. Ook deze mededelingen beogen een oneigenlijke overdracht van verantwoordelijkheid aan belanghebbenden teweeg te brengen; zij zullen althans dit effect hebben. Immers, enige tijd na de verschijning van een dergelijke "verantwoording" hebben de belanghebbenden het morele recht verspeeld om in te grijpen; zij zijn a.h.w. medeplichtig gemaakt, terwijl te betwijfelen valt of een buitenstaander zich uit een beschrijving van een organisatie een oordeel kan vormen.

Onder „meningen” zijn ook te verstaan „verwachtingen”. Het is soms onontkoombaar verwachtingen in een verantwoording te verwerken, en wel indien de uitkomsten van plaatsgevonden gebeurtenissen nog niet bekend zijn; men spreekt dan in het algemeen van ,schattingen”. Indien schattingen een meer dan normale betekenis hebben ligt het voor de hand in de verantwoording zoveel in. formatie over de onzekere omstandigheden te geven dat degene die daarvan kennis neemt zijn eigen verwachting kan vormen en deze kan vergelijken met die van de verantwoordingsplichtige.

Verwachtingen omtrent de uitkomsten van activiteiten die nog niet plaatsge. vonden hebben (prognoses) kunnen uiteraard nooit onderwerp van een verant. woording zijn; men kan niet verantwoordelijk zijn voor iets wat nog niet gebeurd is.

\section{Beperking tot het eigen bereik}

De verantwoording dient zich te beperken tot de uitkomsten voor de persoon c.q. het samenwerkingsverband zelf en behoort zich niet verder uit te strekken dan tot de gevolgen aan eigen kant van de relaties met belanghebbenden. De gevol. gen bij de belanghebbenden behoren buiten de verantwoording te blijven.

Deze beperking tot wat ik maar met het „eigen bereik” aanduid, heeft een aantal redenen. Ten eerste lijkt er geen reden te bestaan waarom een belanghebben. de zich een onderzoek naar de gevolgen van zijn relatie met de verantwoordingsplichtige zou moeten laten welgevallen. Voorts zijn gevolgen vaak moeilijk aan één oorzaak toe te rekenen; indien een belanghebbende stelt dat de relatie hem 
ongunstige uitkomsten oplevert, dan zou de bewijslast op onredelijke wijze omgekeerd worden als de verantwoordingsplichtige dergelijke uitkomsten in zijn verantwoording zou moeten opnemen. Ook kan de verantwoordingsplichtige nauwelijks voor de betrouwbaarheid van die informatie instaan.

Maar de belangrijkste reden is, dat belanghebbenden een enorme macht over de verantwoordingsplichtige zouden krijgen indien deze verplicht zou worden (direct of indirect) van belanghebbenden afkomstige informatie in zijn verantwoording op te nemen; dit zou tot zelfbeschuldiging kunnen dwingen. In een vrije maatschappij past een dergelijke macht niet.

Degenen die regelmatig kennis nemen van de thans gebruikelijke verantwoordingen zullen wellicht wat verbaasd zijn over de lengte van het betoog op dit punt. In een jaarverslag vindt men wel de winst per aandeel en het dividend, doch niet de koerswinsten of -verliezen die (gewezen) aandeelhouders op hun aandelen in de desbetreffende vennootschap hebben behaald resp. geleden. Dit vloeit voort uit de beperking van de verantwoording tot het eigen bereik.

Deze beperking is echter bepaald geen gemeengoed onder degenen die zich met maatschappelijke verslaggeving bezighouden. Ik beperk mij tot een enkel voorbeeld: op de Accountantsdag 1978 stelde Brevoord voor de uitslag van een periodiek onderzoek naar de mate van bevrediging in het werk bij werknemers in het maatschappelijk verslag op te nemen; dat onderzoek zou ongeveer ${ }^{1}$ ) moeten geschieden door de werknemer in een soort geheime stemming een kruisje te doen zetten bij een omschrijving die kon variëren van „heel tevreden” tot „heel ontevreden".

Gegeven het feit dat deze informatie gepubliceerd zou moeten worden, zou een werknemersorganisatie hiermee een geweldig machtsmiddel in handen krijgen. Het zal duidelijk zijn dat ik van mening ben dat een vrije maatschappij niet met een dergelijke ontwikkeling gediend is. Dergelijke voorstellen bevorderen de totstandkoming van de maatschappelijke verantwoording niet.

Met de drie geschetste grenzen is, naar ik meen, het karakter van de inhoud van een verantwoording bepaald. Ik zou het begrip ,verantwoording” dan ook willen omschrijven als:

„een door een verantwoordingsplichtige in die kwaliteit gedane mededeling, inhoudende de binnen zijn bereik liggende feitelijke gevolgen van zijn activi. teiten".

In de toelichting op het ontwerp voor de Gedrags- en Beroepsregels Registeraccountants (8) is opgemerkt dat: ,verantwoording niet slechts inhoudt de mededeling van degene die zich moet verantwoorden, doch elke kwantitatieve voorstelling van feitelijkheden voor zover daaraan een verantwoordingskarakter moet worden toegekend". De opstellers van de toelichting hebben toegegeven dat deze omschrijving door het invoegen van het ,verantwoordingskarakter" een tautologisch karakter heeft (8), en genoemde toelichting refereert dan ook verder aan het spraakgebruik. Voorts concludeert Frielink (10) uit de beraadslagingen bij de vaststelling van de GBR dat ook kwalitatieve mededelingen een verantwoor. dingskarakter kunnen hebben.

\footnotetext{
1) $\mathrm{Er}$ is geen woordelijk verslag van deze bijeenkomst gepubliceerd; cen globaal verslag is opgenomen in De Accountant van juli/augustus 1978; zic daarin blz. 646 .
} 
Bij de vergelijking met de door mij gegeven omschrijving vallen de volgende verschillen op:

- laatstbedoelde omschrijving beperkt zich niet tot kwantitatieve voorstellin. gen, maar legt de grens direct bij de feitelijkheden;

- de verruiming tot kwalitatieve mededelingen lijkt niet onder de door mij ge. geven omschrijving te vallen; het komt mij voor dat het hier in het algemeen om meningen (van de verantwoordingsplichtige!) zal gaan.

Het door Frielink gegeven voorbeeld: een mededeling van de leiding van een computer-servicebureau, inhoudende dat de organistie en de werkwijze van dit bureau voldoen aan de daaraan te stellen eisen van beveiliging en controle, is in mijn ogen stellig geen verantwoording, doch een mening over het eigen beleid.

Voorts heeft de door mij gegeven omschrijving met die van het ontwerp GBR gemeen dat het begrip ,verantwoording” niet beperkt is tot financiële gegevens, en dat ook mededelingen in het kader van de afwikkeling van overeenkomsten met, of andere verplichtingen aan belanghebbenden eronder vallen. De door mij gegeven omschrijving spreekt dan ook niet van „beheer”, maar van ,activiteiten”.

Wat onder een verantwoording verstaan wordt, is ook van belang voor de toe. passing van de GBR. Daarin wordt onderscheid gemaakt tussen verklaringen en overige mededelingen van accountants; voor verklaringen gelden verder gaande bepalingen dan voor overige mededelingen. Verklaringen kunnen per definitie alleen bij verantwoordingen worden gegeven.

Ik ben van mening dat de bepalingen van de GBR inzake verklaringen goed passen bij het verantwoordingsbegrip als door mij omschreven. Anderzijds vloeien de reglementaire moeilijkheden die men ondervindt bij het ontwerpen van ,verklaringen” bij prognoses en bij beschrijvingen van een organisatorische opzet, voort uit het feit dat deze stukken van nature geen verantwoording zijn. Bemoeienissen van accountants met dergelijke stukken kunnen stellig zinvol zijn, en dus moeten er ook zinvolle mededelingen omtrent de uitkomst van die arbeid gedaan kunnen worden, maar deze zullen een ander karakter moeten hebben dan verklaringen. Overigens moet bij de redactie van dergelijke mededelingen zorgvuldig vermeden worden de indruk te wekken dat de accountant promotorswerkzaamheden verricht.

Gezien de maatschappelijke functie van de verantwoording moeten er een aantal eisen aan gesteld worden die hierna besproken worden.

\section{Getrouwe weergave}

Dit houdt in dat de verantwoording feitelijk juist moet zijn, geen wezenlijke gegevens mag weglaten, en de informatie duidelijk en met inbegrip van een toereikende toelichting moet presenteren. Voor ruimere verantwoordingen dan jaarrekeningen zal de inhoud van hetgeen getrouw weergegeven dient te worden zich nog geruime tijd moeten ontwikkelen voordat zich een maatschappelijke consensus zal aftekenen.

\section{Toegespitst op de beslissingen van de belanghebbenden}

Binnen het eerder onder de punten $1 \mathrm{t} / \mathrm{m} 3$ geschetste kader moet de verantwoording de belanghebbenden in staat stellen hun beslissing tot voortzetting, 
wijziging of beëindiging van de relatie op goede gronden te nemen. Anderzijds behoren belanghebbenden aannemelijk te maken dat zij bepaalde informatie daartoe nodig hebben; de vrijheid eist mijns inziens deze verdeling van de bewijslast. Hiertoe zal eerst een algemene maatschappelijke discussie gevoerd moeten worden; nadien is voor specifieke zaken te denken aan een (scheids)rechterlijke procedure.

\section{Controleerbaar}

De beperking van de verantwoording tot uitkomsten, tot feiten die binnen het bereik van de verantwoordingsplichtige liggen betekent dat de verantwoording in beginsel controleerbaar is. Maar dat is niet alleen een prettige bijkomstigheid, het is ook een maatschappelijke eis: de juistheid en de volledigheid van de feiten moeten door derden vastgesteld kunnen worden, anders heeft men zich niet echt „verantwoord".

Hoewel de feiten in beginsel vast te stellen zijn, moeten voor de controleerbaar. heid verder gaande eisen gesteld worden, met name aan de betrouwbaarheid van de eerste vastlegging van gegevens. Bij sommige personen en kleine samenwerkingsverbanden kan nimmer aan deze eisen voldaan worden; het verdient dan ook aanbeveling de maatschappelijke verantwoordingsplicht daarvoor niet volledig te laten gelden, mede gezien de vaak betrekkelijk kleine en overzichtelijke kring van belanghebbenden. Anderzijds is het denkbaar dat een verantwoordingsplichtige zich aan zijn plicht onttrekt door zonder noodzaak te weigeren zijn verantwoording controleerbaar te maken; daarin kan - maatschappelijk gezien . uiteraard niet worden berust.

Met dit laatste punt wordt hetgeen de titel aanduidt als het hoofdonderwerp van dit artikel ten tonele gevoerd.

\section{De rol van de accountant}

De verantwoording wordt afgelegd door de verantwoordingsplichtige zelf. Dit is een wezenlijk element van de vrijheid: men verantwoordt zich, men wordt niet door een ander verantwoord.

De inhoud van de verantwoording kan van grote invloed zijn op de relaties met alle mogelijke belanghebbenden, en de verantwoordingsplichtige heeft er dan ook alle belang bij dat uit de verantwoording een voor zijn relaties zo gunstig mogelijk beeld naar voren komt. Maar daardoor kan bij belanghebbenden twijfel aan de geloofwaardigheid van de verantwoording rijzen. De maatschappelijke functie van de accountant vindt hierin zijn bestaansgrond; de primaire maatschappelijke rol van de accountant is: het verlenen van geloofwaardigheid aan verantwoor. dingen.

Deze omschrijving is veel enger dan die waartoe Bindenga (3) komt: het geven van een oordeel over informatie. Door de beperking van het oordeel tot "geloofwaardigheid" en van de informatie tot "verantwoordingen" wordt het door Bin. denga (3) ten tonele gevoerde optreden als „,commissaris algemeen belang” of „eigenlijke vertrouwensman van het maatschappelijk verkeer” uitgesloten. Bindenga meent dat dit optreden alleen nog maar geïnstitutionaliseerd behoeft te worden, en dus in de kiem reeds nu tot de accountantsfunctie behoort. Ik ben van 
mening dat dit een geheel nieuwe functie is die tot een maatschappelijke ommekeer zou leiden, en die stellig niet uit de huidige ontwikkeling is af te leiden. Ik kom hier nog nader op terug.

Door het optreden van de accountant is het probleem van de geloofwaardigheid niet onmiddellijk opgelost: in eerste instantie verschuift het van de verantwoor. dingsplichtige naar de accountant. Belanghebbenden moeten erop kunnen rekenen dat de accountant onpartijdig is, zijn vak verstaat en al het nodige werk goed verricht. Hoe dit alles gewaarborgd wordt, wordt hier niet beschreven; daaraan wordt de laatste jaren veel aandacht besteed, en in een binnenkort verschijnend rapport van de Werkgroep Dynamische Functie-analyse van het NIvRA zal hierop opnieuw uitgebreid worden ingegaan. Wel hoop ik in een afzonderlijke beschouwing over de maatschappelijke verslaggeving nog eens een aantal specifieke aspecten van dit vraagstuk te belichten.

Veel minder aandacht is gegeven aan de verhouding van de accountant tot de verantwoordingsplichtige. Deze moet worden beheerst door het beginsel dat de vrijheid èn de verantwoordelijkheid van laatstgenoemde onverlet blijven. Dit betekent dat de verantwoordingsplichtige evenmin afhankelijk mag worden gemakkt van de accountant als omgekeerd. Een uitwerking op enkele concrete punten volgt hieronder.

\section{Openheid en geheimhouding}

De accountant heeft het recht van inzage van alle gegevens, tegenover de plicht tot geheimhouding. De vrijheid van de verantwoordingsplichtige impliceert het recht zelf zijn mededelingen aan belanghebbenden te doen, tegenover de plicht zich te verantwoorden. Slechts in het uitzonderingsgeval dat de verantwoordings. plichtige zich aan deze plicht onttrekt en de accountant hieraan medeplichtig dreigt te maken, is spreken gerechtvaardigd.

De geheimhouding brengt ook een zekere beperking in de te hanteren controlemiddelen met zich mee; het inschakelen van andere externe deskundigen zal slechts kunnen geschieden indien de verantwoordingsplichtige redelijkerwijs niet kan stellen dat daardoor geheimen worden prijsgegeven.

Openheid in de verhouding tussen verantwoordingsplichtige en accountant kan slechts duurzaam zijn indien deze wederkerig is. Daarom is het ongewenst de accountant te verbieden de verantwoordingsplichtige van advies te dienen.

\section{Geen belangenbehartiging}

De accountant verricht zijn onderzoek van de periodieke beheersverantwoording in het belang van de gezamenlijke belanghebbenden, maar hij mag daarbij niet enig bijzonder belang van een specifieke belanghebbende behartigen: dit zou immers de verantwoordingsplichtige via de accountant afhankelijk maken van die specifieke belanghebbende. Het vorenstaande houdt in dat de accountant in het kader van de opdracht tot controle van de periodieke beheersverantwoording niet gevraagd behoort te worden de naleving te controleren van overheidsvoorschriften die geen betrekking op de verantwoording hebben. Wel kan de accountant een afzonderlijke opdracht tot controle van een specifieke verantwoording 
in het kader van de afwikkeling van een overeenkomst of van een andere ver. plichting aanvaarden; dat is geen belangenbehartiging.

\section{Geen permanent toezicht}

Onderwerp van de controle is slechts de verantwoording, niet de activiteit van de verantwoordingsplichtige. Daarom zijn controlemiddelen die gebaseerd zijn op voortdurend toezicht ontoelaatbaar. Een permanente waarneming die in be. ginsel ten doel zou hebben de volledigheid van de verantwoording vast te stellen, zou ook ongewild de beheersdaden omvatten. Dit is in strijd met de autonomie waarop de verantwoordingsplichtige aanspraak mag maken. $\mathrm{Bij}$ voortdurend toe. zicht treedt onontkoombaar een verlies van onafhankelijkheid van één van beide partijen op. Er zijn overigens nog meer bezwaren tegen voortdurend toezicht; ver. wezen zij naar een eerder verschenen artikel van mijn hand in dit blad (5).

\section{Honorarium voor noodzakelijke arbeid}

De onafhankelijkheid van de accountant brengt met zich mee dat hij in vrijheid de noodzakelijke werkzaamheden moet kunnen vaststellen, en daarvoor ook ge. honoreerd moet worden. Anderzijds moet de verantwoordingsplichtige het vertrouwen kunnen hebben dat hem geen onnodig werk ten laste gebracht wordt.

Voor een rationeel gebruik van de verantwoording door belanghebbenden is volledige exactheid geenszins noodzakelijk. Dit betekent dat rationele beperkin gen kunnen worden aangebracht in de omvang van de verschillende deelonder. zoeken, die overigens te zamen wel een organisch en logisch geheel van controlemaatregelen moeten blijven vormen. Een strikte beperking van het onderzoek tot hetgeen voor de geloofwaardigheid van de verantwoording noodzakelijk is, betekent wel dat verder reikende doelstellingen (b.v. de ontdekking van fraude) niet altijd verwezenlijkt kunnen worden. Zowel de verantwoordingsplichtige als de belanghebbenden dienen zich hiervan bewust te zijn.

In een eerder artikel (4) heb ik gesteld, dat Limpergs „leer van het gewekte ver. trouwen " beter "leer van de rationele verwachtingen" zou kunnen heten. Dat heeft natuurlijk wel de vraag opgeleverd: wat is ,rationeel” in dit verband? Welke verwachtingen kunnen redelijkerwijs in het maatschappelijk verkeer ten opzichte van de accountant gekoesterd worden?

Mijn antwoord is: rationeel zijn die verwachtingen, waarbij aan de accountant een zinvolle, eigen functie wordt toegedacht die in overeenstemming is met de vrijheid èn met de verantwoordelijkheid van de verantwoordingsplichtige. De maatschappelijke verwachtingen zijn niet rationeel indien zij bij vervulling zouden leiden tot onzuivere verhoudingen tussen verantwoordingsplichtige, accountant en belanghebbenden. In het maatschappelijk verkeer geuite verwachtingen moe ten dus hieraan getoetst worden alvorens ze als legitiem door accountants aanvaard kunnen worden. Dat een dergelijke toetsing geen overbodige weelde is, moge blijken uit het volgende voorbeeld.

Eén van de stellingen die door W. Kok, voorzitter van het NVV, voor de Accountantsdag 1975 op schrift (14) is gesteld, luidde: „Er is grote behoefte aan een publiekelijk of naar bepaalde groepen belanghebbenden toe uitgesproken oor. 
deel over het gevoerde bedrijfsbeleid." Kok meent verder dat de accountant hiertoe bij uitstek geschikt is.

In een op die Accountantsdag gegeven en nadien gepubliceerde reactie (6) meen ik reeds te hebben aangetoond dat de accountant hiertoe volslagen ongeschikt is, indien men hem althans wil handhaven als degene die de geloofwaardigheid van verantwoordingen moet verhogen. Kok ziet namelijk over het hoofd dat de ondernemingsleiding bij elke belangrijke beslissing het oordeel van de ac. countant zal vragen, en wel om te voorkomen dat de accountant met achteraf verkregen wetenschap publiekelijk of tegenover derden een minder gunstig oordeel zal uitspreken. In feite moet de accountant dan in alle belangrijke zaken meebeslissen, en dat maakt hem ongeschikt voor de attestfunctie (zie art. 9 lid 3 GBR). Dit is collisie in zijn meest zuivere vorm. Overigens heeft Kok dit in zijn mondelinge repliek toegegeven, zij het dat hij daarbij voorbij ging aan een veel belang. rijker punt, waar ik nog nader op terugkom, en wel bij de bespreking van de maatschappelijke rol van de beroepsorganisatie.

Een variant van het beleidsoordeel is - althans bij een bepaalde interpretatie te vinden in het reeds eerder genoemde Studierapport van de Werkgroep Management Audit van het NIvRA (18), alwaar gesproken wordt over een (mogelijke) verantwoording over de conditie van de organisatie, en certificering daarvan door externe deskundigen. Volgens de werkgroep behoort de rapportering aan de verantwoordingsplichtige zelf uit te monden in een opinie; voor de rapporte. ring aan derden lijkt de werkgroep daar niet aan te denken. Ik meen dat deze laatste mogelijkheid expliciet verworpen moet worden: er is een volkomen pa. rallel met het beleidsoordeel. Tegen het geven van dergelijke oordelen bestaan nog meer bezwaren, o.a. de door Nordemann (17) gesignaleerde poging tot af. wenteling van onverzekerbare onzekerheid op de accountant.

De toetsing van in het maatschappelijk verkeer geuite verwachtingen aan de dichotomie vrijheid/verantwoordelijkheid is een dimensie die nog geheel ontbreekt in recente publikaties van het NIvRA. Het in 1978 afgeronde studierap. port: „De reikwijdte van de accountantsverklaring” (7) bespreekt in hoofdstuk 6 de behoefte aan oordelen van accountants, waarin niet kan worden voorzien. Eén van de gegeven voorbeelden is het beleidsoordeel. De motivering van de afwij. zing geschiedt geheel vanuit het vooralsnog ontbreken van toetsingscriteria bij het onderzoek; men wekt de verwachting dat hierin in de toekomst voorzien zal kunnen worden, dat dit een kwestie van (vak)technische ontwikkeling is. Het moge duidelijk zijn dat ik een principiële bezinning veel meer noodzakelijk acht dan verder gaande research of experimenten.

Ter afsluiting van de beschouwing over de rol van de accountant volgen nog enkele opmerkingen over de term ,vertrouwensman van het maatschappelijk verkeer". De discussie over deze door Limperg (16) geïntroduceerde term is ontstaan doordat buitenstaanders blijk gaven van misverstand over de betekenis. Dat misverstand is niet zonder enige grond. Van Dale omschrijft een vertrouwensman (anno 1976) als „een persoon wien men zekere zaken ter behartiging toevertrouwt"; bij Koenen.Endepols vindt men (in 1974) de vertrouwensman om. schreven als ,iemand die in het vertrouwen zijner opdrachtgevers als tussenpersoon optreedt". Hieruit komt - althans bij mij - het beeld naar voren van een zaak. waarnemer, met zekere volmachten. Dit beeld is strijdig met mijn stelling dat de accountant bij het onderzoek van de periodieke beheersverantwoording geen 
specifieke belangen van groepen belanghebbenden behoort te behartigen. Ik meen dan ook, om dezelfde pragmatische redenen als Bak (1), dat de term in de public relations van het beroep beter niet meer gebruikt kan worden, al onder. schrijf ik gaarne hetgeen Van Kampen (13) en ook Frielink (11) zeggen over de grote, positieve betekenis die deze term voor de vorming van vele accountants heeft gehad.

Ik deel ook in wezen de onvrede die Bindenga (3) met de term heeft, maar zijn poging om tot een gezuiverde vorm, de "eigenlijke maatschappelijke vertrouwensman" te komen, wijs ik af. Kern van die functie is "dat accountants zich uitspreken over bepaalde dingen waarover hun cliënten zich niet willen uitspreken". De accountant neemt dan de verantwoording over, kennelijk zonder de verantwoordelijkheid over te nemen. Dit reduceert de cliënt tot onmondigheid, en maakt de accountant veel machtiger dan te rijmen is met de grondgedachte van de vrije ondernemingsgewijze produktie.

\section{De rol van de beroepsorganisatie}

In de discussie omtrent de maatschappelijke rol van een beroep behoort de des betreffende beroepsorganisatie stimulerend en sturend op te treden. Dit zal in het algemeen een interne organisatorische aangelegenheid zijn, met als resultaat min of meer regelmatige publikaties c.q. publiciteit.

Aan de beroepsorganisatie van accountants worden verder gaande eisen gesteld, omdat dit beroep zijn bestaansgrond vindt in de maatschappelijke relatie tussen verantwoordingsplichtigen enerzijds en belanghebbenden anderzijds. De door Van der Hooft (12) gesignaleerde tendens tot bundeling van maatschappelijke groeperingen in belangenbehartigende instellingen vergroot de noodzaak, maar ook de mogelijkheid tot zinvolle maatschappelijke discussies.

Zoals in de aanvang van dit artikel reeds is gesteld, is de beroepsorganisatie van accountants, het NIvRA, beslist actief op dit terrein, en het vorenstaande mag ze. ker niet als kritiek op dit Instituut worden geïnterpreteerd. Ter afronding van mijn beschouwing wil ik evenwel aandacht geven aan de vraag: wat moet de be. roepsorganisatie in een maatschappelijke discussie inbrengen?

In de eerste plaats moet de beroepsorganisatie waken tegen ontwikkelingen die de functie van de accountant aantasten of onzuiver maken, tegen het wekken van verwachtingen of het stellen van eisen die accountants niet kunnen honore. ren.

Dit is een veelomvattende taak die waakzaamheid op allerlei niveaus vereist. In Nederland hebben (semi-)overheidsinstellingen weinig oog voor de onafhan. kelijkheid van de accountant en zij schrijven dan ook vaak zonder enig overleg verklaringen voor die een accountant moeilijk kan geven. De beroepsorganisatie heeft de onaangename taak zich hiertegen te verzetten.

Op een ander niveau ligt bijvoorbeeld de eerder gereleveerde vraag van Kok om een beleidsoordeel. Gelukkig lijkt de roep hierom - althans buiten de kring van accountants - verstomd, maar indien de discussie voortgezet zou zijn of alsnog hervat zou worden, zou de beroepsorganisatie stellig haar partij moeten meeblazen. En ik meen dat de inbreng niet beperkt zou moeten blijven tot de constatering dat het geven van een beleidsoordeel onverenigbaar is met het geven van een verklaring bij een verantwoording, want het publiekelijk geven van een be- 
leidsoordeel door wie dan ook - heeft consequenties voor de maatschappelijke ordening, die Kok op de Accountantsdag 1975 niet onder ogen wilde zien.

Ik heb reeds gesteld dat degene die een beleidsoordeel moet geven zeer snel in de positie gedrongen zal worden dat hij moet meebeslissen; hij heeft in ieder geval de facto het recht van veto. Om de (schijn van) onafhankelijkheid te bewaren zullen de beleidsbeoordelaars zich in samenwerkingsverbanden moeten ver enigen. Dat worden, nationaal economisch gezien, zeer machtige lichamen: zij domineren in feite het bedrijfsleven. Dergelijke lichamen kunnen, politiek gezien, niet buiten de overheidssfeer blijven, en dan ligt het in de lijn der verwachting dat daaruit een staatsbeheersinstelling voor ondernemingen ontstaat. Dit betekent dan in feite het einde van de vrije ondernemingsgewijze produktie.

Dit scenario mag op het eerste gezicht overtrokken lijken, te bedenken zij dat het evenwicht tussen vrijheid en verantwoordelijkheid, waarop de vrije onderne. mingsgewijze produktie stoelt, door verandering van een enkel element verbro. ken wordt: acties van belangengroeperingen roepen reacties van anderen op, van verantwoordingsplichtigen, van verschillende groepen belanghebbenden, van politici en van de overheid, tordat een nieuwe evenwichtstoestand ontstaat. Hoe dat evenwicht uitvalt is uiteraard voor het beroep van de grootste betekenis.

Ook een verandering in de positie van de accountant kan leiden tot drastische wijzigingen in de maatschappelijke ordening. Een scenario als zojuist voor het beleidsoordeel gegeven kan met dezelfde mate van waarschijnlijkheid worden opgesteld voor de gevolgen van ingrepen als het afschaffen van de geheimhoudingsplicht, het loskoppelen van advies- en controlefunctie en het afschaffen van de vorm van vrij beroep voor de uitoefening van de accountantsfunctie. Dergelijke ingrepen zouden niet op zichzelf kunnen blijven, zij zouden een labiele situatie doen ontstaan en steeds nieuwe ingrepen noodzakelijk maken, ook in de verhouding tussen verantwoordingsplichtige en belanghebbenden. De beroepsorganisatie behoort uiteraard attent te zijn op dergelijke ontwikkelingen.

Men kan zich afvragen of hetzelfde ook geldt voor ontwikkelingen die zich afspelen tussen verantwoordingsplichtigen en belanghebbenden zonder dat de accountants er (vooralsnog) bij betrokken zijn. Een voorbeeld hiervan is de vraag of een verantwoordingsplichtige prognoses, of een beschrijving van zijn organisatie moet overleggen aan belanghebbenden; dergelijke ontwikkelingen kunnen heel goed van fundamentele betekenis blijken voor (het evenwicht in) de verhouding tussen deze twee groeperingen. Hoewel accountants zich thans naar mijn gevoel méér met dergelijke vormen van informatieverstrekking bezighouden dan de be. trokkenen zelf, is deze analyse in beroepskringen nog achterwege gebleven. Dit probleem verdient naar mijn mening een hogere prioriteit dan de vraag welke mededeling (in geen geval een verklaring!) een accountant bij deze informatie zou kunnen geven.

In een maatschappelijke discussie over dergelijke aangelegenheden heeft de beroepsorganisatie de beste positie om neutraal de te verwachten gevolgen van allerlei ontwikkelingen te analyseren en onder de aandacht te brengen, en daardoor een stabiliserende invloed uit te oefenen. Deze rol moet niet geschuwd worden. 


\section{Samenvatting}

In een vrije maatschappij kan de ondernemingsgewijze produktie zich op een maatschappelijk gunstige wijze ontplooien indien de verantwoordelijkheid voor het gebruik van de vrijheid erkend wordt. Die erkenning wordt belichaamd in het afleggen van verantwoording. Aard en inhoud van een verantwoording zijn in het licht van verantwoordelijkheid en vrijheid van de verantwoordingsplichtige in zijn relatie tot belanghebbenden geanalyseerd.

Ook de rol van de accountant moet passen in deze relatie. Belangrijke aspecten van de verhouding van de accountant tot de verantwoordingsplichtige zijn in het kort besproken. De verwachtingen van belanghebbenden kunnen eerst redelijk genoemd worden indien zij in overeenstemming zijn met de vrijheid èn met de verantwoordelijkheid van de verantwoordingsplichtige.

Nieuw geuite verwachtingen moeten in de eerste plaats hieraan worden getoetst. De beroepsorganisatie zal hierin een actieve rol moeten spelen; dit geldt ook voor ontwikkelingen in de verhouding tussen verantwoordingsplichtige en belanghebbenden waar de accountant vooralsnog niet bij betrokken is.

\section{Literatuurverwijzingen}

1. G. G. M. Bak, De accountantsfunctie in de maatschappij (2), M.A.B. maart 1975 , blz. 117.

2. A. J. Bindenga, Het vrije beroep van accountant, Samsom 1973.

3. A. J. Bindenga, De accountantsfunctie in de maatschappij, M.A.B. maart 1975, blz. $111 \cdot 112$

4. J. H. Blokdijk, Een kernvraagstuk van de leer der accountantscontrole (I), M.A.B. april 1975, blz. 148 .

5. J. H. Blokdijk, T.a.p., blz. 156157.

6. J. H. Blokdijk, Enkele notities inzake het beleidsoordeel, De Accountant augustus 1975 , blz. 675.

7. College voor Beroepsvraagstukken van het NIvRA, Studierapport: De reikwijdte van de accountantsver klaring, NIvRA 1978, blz. 36-38.

8. Commissie Herziening Beroepsregelen van het NIvRA, Ontwerp van Verordening houdende Gedrags en Beroepsregels Registeraccountants (GBR), opgenomen in de uitgave "Van R.B.R. tot GBR", NIvRA 1975 , blz. 158 en $288 \mathrm{t} / \mathrm{m} 296$.

9. Commissie Toekomstverkenning van het NIvRA, rapport: „De Accountant, morgen?", NIvRA ।971.

10. A. B. Frielink, De GBR verklaart, Kosmos 1974, bl2. 5.

11. A. B. Frielink, De openbare accountant: vertrouwensman in en van het maatschappelijk verkeer, De Ac countant februari 1976, blz. 320-321.

12. W. J. van der Hooft, Maatschappelijk verkeren, in: Accoord, afscheidsbundel Prof. Drs. A. A. de Jong, Erasmus Universiteit Rotterdam 1976, blz. 245-248.

13. L. van Kampen, De openbare accountant: vertrouwensman van het maatschappelijk verkeer?, De Accoun tant mei 1976 , blz. 484.485 .

14. W. Kok, De maatschappelijke behoefte aan ondernemingsinformatie, De Accountant maart 1975 , blz. 424 .

15. Th. Limperg Jr., De betekenis van de accountantsverklaring in verband met de verantwoordelijkheid van de accountant, Tweede Internationale Accountantscongres, 1926.

16. Th. Limperg Jr., De functie van de accountant en de leer van het gewekte vertrouwen, M.A.B. 1932/33, opgenomen in de bundel „Vijftig jaar M.A.B.”, deel 2 Accountancy, blz. 228.230.

17. H. H. J. Nordemann, De accountant in een veranderende wereld, Van Gorcum 1972, blz. 17.

18. Werkgroep Management Audit van het NIvRA, Studierapport NIvRA 1978, blz. 25. 